\title{
MATHEMATICS COMMUNICATION JUNIOR HIGH SCHOOL STUDENTS IN SOLVING OPEN-ENDED QUESTION BASED ON REFLECTIVE-IMPULSIVE COGNITIVE STYLE
}

\author{
Eka Zulia Ningtyas ${ }^{1}$, Masriyah ${ }^{2}$ \\ ${ }^{1,2}$ Universitas Negeri Surabaya \\ e-mail: $\underline{1}$ eka.17030174002@mhs.unesa.ac.id,,$\underline{2}$ masriyah@unesa.ac.id
}

\begin{abstract}
Abstrak
Komunikasi matematika merupakan salah satu kemampuan penting siswa terkait menyampaikan ide baik secara tulis maupun lisan yang dapat diukur dengan memberikan soal untuk diselesaikan. Salah satu faktor yang mempengaruhinya adalah gaya kognitif yang menunjukkan kecepatan berpikir adalah gaya kognitif reflektif dan impulsif. Tujuan penelitian ini mendeskripsikan komunikasi matematika seorang siswa SMP reflektif dan seorang siswa SMP impulsif dalam menyelesaikan soal open-ended. Penelitian ini merupakan penelitian deskriptif dengan pendekatan kualitatif. Pengumpulan data melalui tes dan wawancara. Subjek dipilih dengan teknik purposive sampling. Hasil penelitian menunjukkan komunikasi matematika tulis siswa reflektif dalam menyelesaikan soal open-ended lancar, lengkap dan cenderung akurat namun komunikasi lisannya cenderung tidak lancar, tidak akurat dan tidak lengkap. Sedangkan komunikasi tulis siswa impulsif dalam menyelesaikan soal open-ended lancar, lengkap tetapi tidak akurat namun komunikasi lisannya lancar, lengkap cenderung tidak akurat.
\end{abstract}

Kata kunci: Komunikasi Matematika, Soal Open-ended, Gaya Kognitif Reflektif, Gaya Kognitif Impulsif.

\begin{abstract}
Mathematics communication is one of important abilities about conveying ideas in writing and orally which measured by providing open-ended questions to solve. One of factors which influenced it is reflective-impulsive cognitive style. The purpose of this study describes the mathematics communication of a reflective and an impulsive junior high school student in solving open-ended questions. This research is a descriptive study with a qualitative approach. Data collected through test and interview. Subject was selected using purposive sampling. The results showed reflective students did written mathematics communication fluently, completely and tend to be accurate, but her oral communication tends to be influent, inaccurate and incomplete. Meanwhile, impulsive students did written communication fluently, completely but inaccurately, but her oral communication is fluent, complete, tends to be inaccurate.
\end{abstract}

Keywords: Mathematics communication, Open-ended question, Reflective cognitive style, Impulsive cognitive style.

\section{Introduction}

Mathematics communication is one of important ability about student could express their idea by oral or written. It also relates with the goal of mathematics lesson in Kurikulum 2013. Rohid dan Retno [1] also stated that mathematics communication could describe deep understanding about concept. In the other hand, several studies conducted by, Wijayanto et al. 
[2], Rohid and Retno [1], Rizqi, and Wiyanto [3] stated that mathematics communication among junior high school students in Indonesia still low and a innovation is needed to develop it.

One of student abilities that is also related to mathematics communication is problem solving. Supported by Wahyuningrum and Suryadi's [4] research results that there is a strong relationship between problem solving and mathematics communication. Based on those statements, to measure students' mathematics communication can be done by providing questions to be solved by students. However, often the questions given to students are closeended questions, which have only one correct answer [5]. The impacts of that according to Sapitri et al. [6] is lack of students' creativity in solving problems. So, it possible create low abilities of problem-solving which have an impact on students' ability to communicate their ideas.

Types of questions based on many possible correct answers and which students rarely encounter are open-ended questions that also require respondents to formulate a response in their own words and to express it verbally or in writing [7]. Although it takes more time to be solved than close-ended, Copeland [8] said that open-ended questions give a chance for students to use variety of ideas and abilities. Students who are trained in developing the mind and concept are more frequent and free, the ability to solve problems will also develop. Therefore, open-ended questions can be an innovation to find out students' mathematics communication.

In process of solving and communicating the solutions each individual is influenced by several factors, one of them is cognitive style. Even the idea of solving problems depend on their cognitive style [9]. Cognitive styles that are related to time and show the speed of thinking are reflective and impulsive cognitive styles. According to Arofah and Masriyah [10] the impulsive cognitive style takes a short time to respond but tends to make mistakes while the impulsive cognitive style is careful and takes time to consider various aspects. Based on these differences, it allows for differences in ways of thinking in solving problems, and differences in oral and written communication.

Gani, et al. [11] stated that in open-ended work that has many answers and many solutions, cognitive style affects his ability to solve problems. Meanwhile research conducted by Noor [12] stated that there is an increase in mathematics communication skills through openended problems. This strengthens if there is a relationship between communications skills in solving open-ended questions, as well as solving it is influenced by the cognitive style of each individual. From these various explanations it can be concluded that there is a relationship between oral and written mathematics communication in solving open-ended questions with a cognitive style, but there has been no research linking students' mathematics communication with reflective-impulsive cognitive style in solving open-ended problems.

Based on the above background, research questions are (1) how is mathematics communication of junior high school student with reflective cognitive style in solving openended questions? (2) how is mathematics communication of junior high school student with impulsive cognitive style in solving open-ended questions?. This study describes the mathematics communication of junior high school student with reflective cognitive style in solving open-ended questions and to describe mathematics communication of junior high school student with impulsive cognitive style in solving open-ended questions.

\section{Research Method}

In this research data was analyzed qualitatively. This study involved the $9^{\text {th }}$ grade as many as 10 students from a school in Gresik which selected using purposive sampling technique based on the results of math ability test, MFFT test and sex control. As many as two samples, one reflective student and one impulsive student, were recruited by considering high math ability (score difference $\leq 5$ ). They were given mathematics communication test which contains openended questions of linear equation two variable that must be completed in 30 minutes to gain written communication data. After that they were interviewed about their work to examine their oral mathematics communication. The written mathematics communication test and interview 
were done twice, to test credibility of data. To get valid data, the researchers validated the instruments. See those validated instruments for this research in Figure 1.

FIRST TEST (Duration 30 minutes)

Mrs. Yuli and Mrs. Lia went to the Miroti Boutique which sells various batik and songket fabrics. The boutique sells in size $250 \mathrm{~cm}$ x $110 \mathrm{~cm}$ for each pieces. Mrs. Yuli bought two pieces of batik and three pieces of songket, the total price paid was IDR $15,800,000.00$. Mrs. Lia bought one piece of batik and two pieces of songket, the total price paid was IDR 9,900,000.00. One day, Mrs. Eka wants to buy 10 pieces of cloth at the Miroti boutique by preparing IDR 30,000,000.00.

According to Mrs. Lia, the money that Mrs. Eka has is enough to buy 10 pieces of cloth. However, according to Mrs. Yuli, Mrs. Eka's money was not enough to buy 10 pieces of cloth.

What do you think? Can Mrs. Eka buy 10 pieces of cloth at the boutique? Give Your Reason!

SECOND TEST (Duration 30 minutes)

Yuli and Lia go to an Cute Accessories Shop that sells various types of masks. There are 2 types of masks that are sold, namely cloth masks and medical masks. The shop sells masks in retail. Yuli bought two medical masks and three cloth masks for a total price of IDR 18,500.00. Lia bought one medical mask and two cloth masks for a total price of IDR 10,000.

Eka intends to buy 10 masks at the shop but only has Rp.30,000. Get Eka to buy 10 masks! Give your reasons!

\section{Figure 1 The Instrument of Written Open question Mathematics Communication Test}

Data were collected mainly through (i) mathematics ability test (ii) MFFT test (iii) written mathematics communication test and (iv) interview. Data analysis for mathematics ability test was based on the assessment guidelines that the researchers had prepared. While the MFFT test data analysis technique was calculated by calculating the average frequency of the selected answers and the average time for the first time subjects answered. For analysis data written mathematics communication test guided by written mathematics communication indicators related to accuracy, completeness and fluency. Meanwhile, the interview analyzed by analysis steps according to Sugiyono [13, p. 337] which includes three stages, namely data reduction, data presentation and conclusion drawing. The indicators which used as a reference in analyzing mathematics communication (MC) data in solving open-ended questions are in Table 1.

Table 1 Indicators of Mathematics communication in Solving Open-ended Questions

\begin{tabular}{|c|c|c|c|c|}
\hline \multicolumn{2}{|l|}{ Indicators } & \multirow{2}{*}{ Aspect } & \multirow{2}{*}{$\begin{array}{l}\text { Mathematics } \\
\text { communication }\end{array}$} & \multirow{2}{*}{ Code } \\
\hline & Condition & & & \\
\hline $\begin{array}{l}\text { Write down all the information to the con } \\
\text { the specified time limit. }\end{array}$ & lusion within & Fluency & Written & L.T.1 \\
\hline \multirow{5}{*}{$\begin{array}{l}\text { Mention the related information that is } \\
\text { known and asked about Open-ended } \\
\text { questions }\end{array}$} & \multirow{2}{*}{ Correctly } & \multirow{2}{*}{ Accuracy } & Written & A.T.1 \\
\hline & & & Oral & A.L.1 \\
\hline & \multirow{2}{*}{$\begin{array}{c}\text { All } \\
\text { information }\end{array}$} & \multirow{2}{*}{ Completeness } & Written & C.T.1 \\
\hline & & & Oral & C.L.1 \\
\hline & Fluent & Fluency & Oral & L.L.2 \\
\hline $\begin{array}{l}\text { Mention the reasons and strategies used } \\
\text { to solve Open-ended questions }\end{array}$ & Correctly & Accuracy & Oral & A.L.2 \\
\hline \multirow{2}{*}{$\begin{array}{l}\text { Mention mathematical terms, notations } \\
\text { and symbols. }\end{array}$} & \multirow{2}{*}{ Correctly } & \multirow{2}{*}{ Accuracy } & Written & A.T.3 \\
\hline & & & Oral & A.L.3 \\
\hline \multirow{5}{*}{$\begin{array}{l}\text { Mention the steps for solving Open- } \\
\text { ended questions }\end{array}$} & \multirow{2}{*}{ Correctly } & \multirow{2}{*}{ Accuracy } & Written & A.T.4 \\
\hline & & & Oral & A.L.4 \\
\hline & \multirow{2}{*}{ All steps } & \multirow{2}{*}{ Completeness } & Written & C.T.2 \\
\hline & & & Oral & C.L.2 \\
\hline & Fluently & Fluency & Oral & L.L.2 \\
\hline \multirow{5}{*}{$\begin{array}{l}\text { Mention possible solutions and } \\
\text { conclusions that are relevant to Open- } \\
\text { ended questions }\end{array}$} & \multirow{2}{*}{ Correctly } & \multirow{2}{*}{ Accuracy } & Written & A.T.5 \\
\hline & & & Oral & A.L.5 \\
\hline & \multirow{2}{*}{$\begin{array}{l}\text { More than } \\
\text { one } \\
\text { solutions }\end{array}$} & \multirow{2}{*}{ Completeness } & Written & C.T.3 \\
\hline & & & Oral & C.L.3 \\
\hline & Fluently & Fluency & Oral & L.L.3 \\
\hline
\end{tabular}




\section{Result and Discussion}

The research data was collected since 29 November to 3 December 2020 by online. The following is a list of selected subjects from 10 junior high schools students in Gresik which have been tested the mathematics ability, and have been classified as reflective cognitive style and impulsive cognitive style presented in Table 2.

Table 2 Research Subjects

\begin{tabular}{ccccccc}
\hline No. & $\begin{array}{c}\text { Initial } \\
\text { Name }\end{array}$ & Gender & $\begin{array}{c}\text { Cognitive } \\
\text { Style }\end{array}$ & $\begin{array}{c}\text { Mathematics Test } \\
\text { Score }\end{array}$ & $\begin{array}{c}\text { Mathematics } \\
\text { Ability }\end{array}$ & Code \\
\hline 1. & FNM & Female & Impulsive & 90 & High & SI \\
\hline 2. & NMEM & Female & Reflective & 90 & High & SR \\
\hline
\end{tabular}

Mathematics communication of Reflective Student in Solving Open-ended Questions
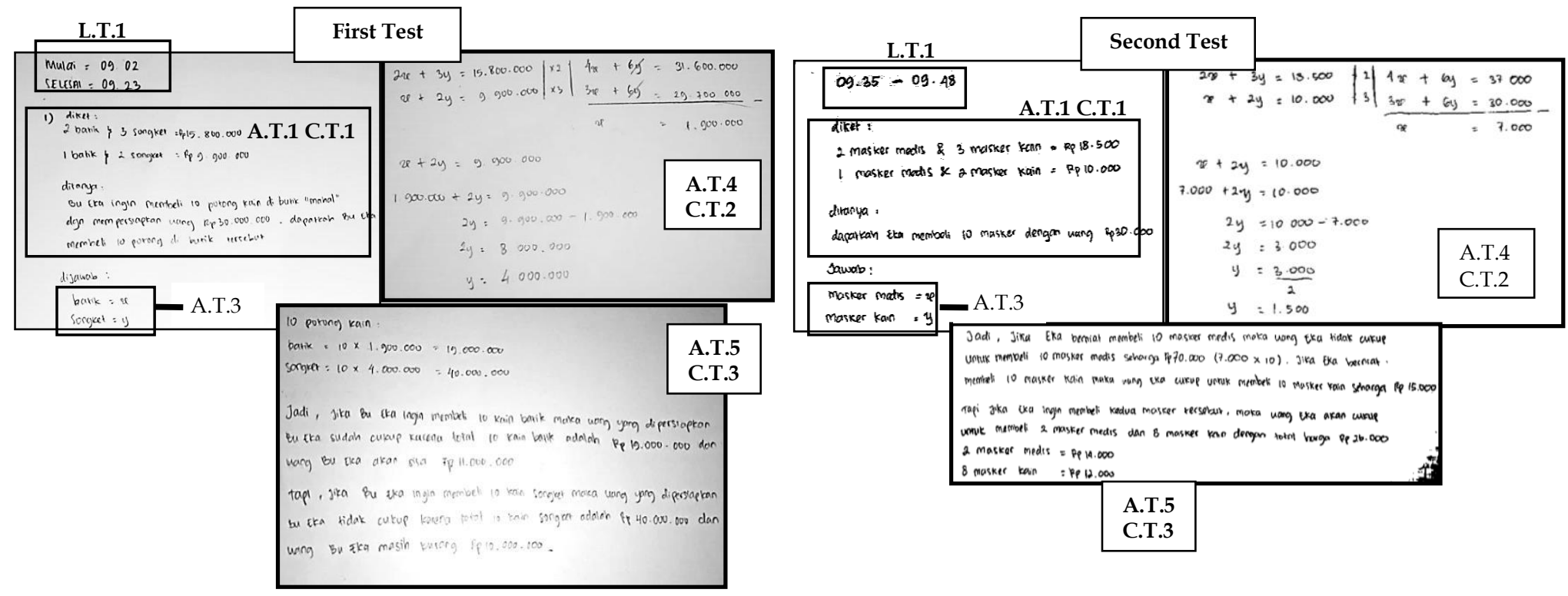

Figure 2 Reflective Student's Work

In Figure 2, L.T.1 shows that the SR subject solved the problem with a duration of less than 30 minutes. This indicates that the written mathematics communication of SR subjects was fluent. This relates with the results of research by Margarani [14] which stated that reflective students can fluently write all information to the conclusion and the results of Shodiqin's research [15] stated that reflective subjects write completely full step by step until the final results are obtained.

Then A.T.1 and C.T.1 indicate that the SR subject wrote all the information that was known and asked that was relevant in the questions correctly and in detail. This indicates that the written mathematics communication of the SR subject related to the information on the questions was accurate and complete. These results are in accordance with Shodiqin's [16] research that reflective students are able to write down things that are known and asked completely and correctly. Following are the interviews of researchers with SR subjects related to information that is known and asked in open-ended questions.

Researcher: What information do you get on this question?

\section{SR Subject}

The first test: About the price of 2 batik and 3 songkets and the price of 1 batik and 2 songkets. (A.L.1)

(C.L.1)

The second test: The price of 2 medical masks and 3 cloth masks is 18,500 and the price of 1 medical mask and 2 cloth masks is 10,000. (A.L.1) (C.L.1)

Researcher: What was asked on the question?

SR Subject

The first test: Enough or not, Mrs. Eka's money to buy 10 pieces of cloth at the Miroti boutique (A.L.1)

(C.L.1)

The sorond tost Can Fka huv 10 masks for 30 thousand (A.I.1) (C.I.1)

Figure 3 Interview Transcript of SR About Known and Asked Information 
Code A.L.1 C.L.1 on the interview transcript, the SR subject mentioned relevant information that was known and asked in open-ended questions in her own language fluent and correct, but not all information is mentioned. This was because the SR subject felt enough that the information is to help him solve the problem. It can be interpreted that the oral mathematics communication of the SR subject was accurate, fluent but incomplete in mentioning related information that is known and asked in open-ended questions. The results of Margarani's [14] research analysis also stated that reflective subjects use short sentences to communicate their ideas.

To find out the chosen strategy and the reasons, researchers conducted interviews with SR subjects. The following are the interview regarding the strategy chosen by the SR subject and the reasons.

Researcher: How did you solve the problem?
SR Subject

The first test: Uses a combined substitution elimination method. The first one looking for the depleted $\mathrm{x}$ value is substituted to find the $\mathrm{y}$ value. For $\mathrm{x}$ as batik and $\mathrm{y}$ for songket. (A.L.2)

The second test: By using of a combined elimination substitution method. (A.L.2)

Researcher: Why did you choose this method?

SR Subject

The first test: Usually in story problems using the combined method. (A.L.2)

The second test: Usually that method is used in story problems and it is quite easy in my opinion. (A.L.2)

Figure 4 Interview Transcript of SR about Solution Strategy

In the transcript of the interview, the SR subject mentioned the strategies she used to solve the questions. This was true according to the procedure she wrote down, it can be said that the oral communication of the SR subject is accurate regarding the settlement strategy.

In code A.T.3, the SR subject used the $x$ and $y$ as variables to model the problem. However, those variables were not accurate in determining what aspects of the information the questions know about. This indicates that written mathematics communication in SR subjects was not accurate in using mathematical notation in the problem. This is in accordance with $\mathrm{L}$, Putri's [17] research that reflective subjects use mathematical notation but its use is not yet correct.

Furthermore, the solution steps written by the SR subject (in code A.T.4 and C.T.2) was complete and correct according to the SPLDV substitution and elimination methods. It can be inferred that the written communication of the SR subject in mentioning the steps was accurate and complete. This is in accordance with Satriawan's [18] research that reflective students wrote correctly and completely every step of solving the problem. Here are the interviews with SR subjects related to completion steps.

Researcher: Try to explain the steps to solve the problems you have written. SR Subject

The first test: The first one uses elimination method, $x$ describes batik and $y$ is songket. Then multiply by 2 over the bottom (pointing to the equation) from what the name is ... from the numbers 2 and 3 it becomes $4 x+6 y=31,600$ which is below $3 x+6 y=29,700$. $6 y$ because it same and positive then it is substracted. Then $4 x-3 x=x$ then $31,600-29,700=1,900,000$, right, so $1,900,000$ is the price of 1 piece of batik cloth. Then I substituted $x+2 y=9,900,000$ because the $x$ was $1,900,000$ so it was put here (pointing to the variable $\mathrm{x}$ ) and then the $x$ was moved to the right side so it was reduced. $2 y=$ $8,000,000, y=4,000,000$ that's from 8 million divided by 2. You get the price of a piece of songket 4,000,000. (A.L.4) (L.L.2) (C.L.2)

The second test: For example $x$ medical masks and fabrics masks $\mathrm{y}$. The elimination method first, $2 x+$ $3 y=18,500, x+2 y=10,000$. Here I find the value $y$, so the top multiplied by 2 becomes $4 x+6 y=$ 37,000 , the bottom is multiplied by 3 becomes $3 x+6 y=30,000$. Since $y$ has the same number em ... it is reduced we get $x=7,000$. Then substitute, I use $x+2 y=10,000$, the $x$ is entered 7,000 $+2 y=$ 10,000 . Then 7,000 is moved to the right to $2 y=10,000-7,000$ then $2 y=3,000$ then 2 is moved to the right to become $3000 \div 2$ then $y=1,500$. So, the price of each medical masks is 7,000 for fabrics masks 1,500. (A.L.4) (L.L.2) (C.L.2) 
Based on the results of the interviews on both tests, the SR subject explained all the step completely, but the SR subject was not fluent and the sentences, terms and examples she used were incorrect, such as misread the numbers that should have been 31,600,000 became 31,600, confusion about the term equation also coefficients. Based on the explanation above, the oral mathematics communication of the SR subject can be said to be not fluent, inaccurate but complete in mentioning the steps for solving open-ended problems and also not accurate in mentioning mathematical terms / notations. The results of Margarani's [14] research stated that reflective students explain the calculation steps accurately, completely and fluently. The difference in the accuracy of oral communication can be due to the SR subject experienced problems in conveying the solution with the correct sentence. This is in accordance with the results of research by L, Putri [17], reflective students do not use complete sentences so they have difficulty communicating even though the answers obtained are correct.

In the conclusion she wrote, codes A.T.5 and C.T.3 indicate if the SR subject wrote more than one alternative correct solution according to what was asked in the question using her own language. Even on the second test the SR subject was able to add one more solution. Based on indicators, written mathematics communication in SR subject in mentioning solutions and conclusions was accurate and complete. The following are the interview regarding the conclusion of the completion of the open-ended questions on the SR subject.

Researcher: Ok, now try to explain the solution and conclusion for the question. SR Subject

The first test: So, if Mrs. Eka wants to buy 10 pieces of batik cloth then Mrs. Eka's money is still left over because 10 pieces of batik cloth cost 19 million but if Mrs. Eka wants to buy 10 pieces of songket cloth, Mrs. Eka's money is still 10 million because 10 pieces of cloth. songket 40 million. In conclusion, Mrs. Eka's money is only enough to buy 10 pieces of batik and still not enough to buy 10 pieces of songket. (A.L.5) (L.L.4) (C.L.3)

The second test: Eka's money is 30,000 and if you want to buy 10 medical masks, Eka's money is not enough because the price of 10 medical masks is 70,000 , whereas if Eka wants to buy 10 fabrics maskswhich costs 15,000, Eka's money is still enough to buy them but if Eka wants to buy both masks. Eka can buy 2 medical masks for 14,000 and 8 fabrics masksfor 12,000 with a total price of both 26,000. So the conclusion is that if Eka's money is 30,000 and wants to buy 10 masks, then she can buy 10 fabrics masksfor 15,000 or 2 medical masks and 8 fabrics masks for a total price of 26,000. (A.L.5) (L.L.4) (C.L.3)

Researcher: Why did you write down 2 solutions in the first test while the second test wrote 3 solutions?

SR Subject: The first and second tests have the same form of questions, the reason for giving 3 solutions in the second test is because I learned from the first test if there are other solutions, not just the 2 solutions.

Figure 6 Interview Transcript of SR about Solution and Conclusion

The SR subject when being interviewed was able to explain more than one alternative solution to the problem and also the conclusions correctly and fluently. Therefore, the oral communication of the SR subject in mentioning alternative answers and conclusions was accurate, complete and fluent. This is in accordance with the results of research by Margarani [14] which states that reflective students are able to speak conclusions accurately, completely and fluently and also in accordance with Shodiqin (2020) which stated that states students can conclude completely and clearly both in write and verbal. In addition, on the first solution the SR subject only wrote 2 solutions correctly but on the second solution she wrote 3 solutions correctly. The reason for the different solutions formulated by the SR subject was because she realized the similarity of the two questions and took lessons from the first test that she relized there are other solutions. This indicates that the SR subject was able to communicate her increasing understanding. In accordance with the research results of Noor [12] that there is an increase in mathematics communication through providing open-ended problems. 
Mathematics communication of Impulsive Student in Solving Open-ended Questions
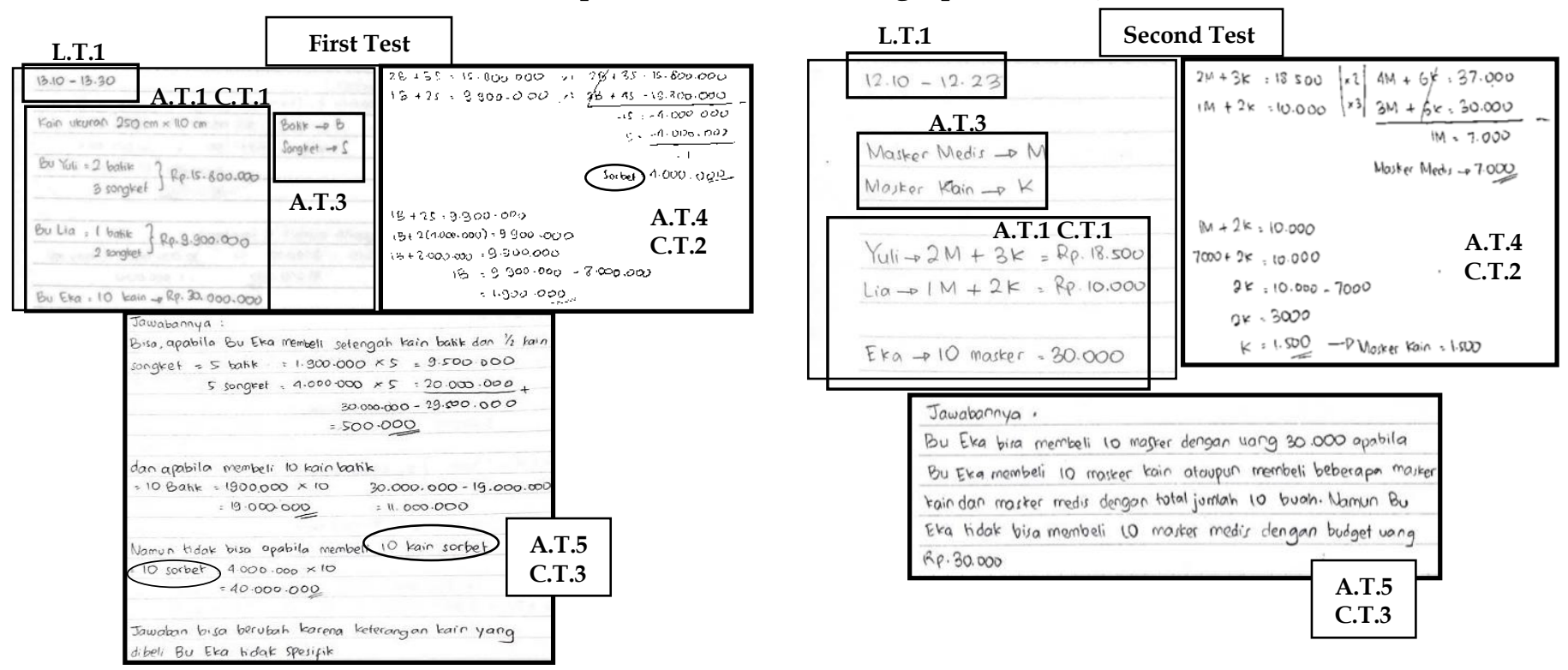

Figure 7 Impulsive Student's Works

In Figure 7, the code L.T.1 shows if the SI subject has completed a question with duration less than the duration given by the question, which is 30 minutes. This indicates that the written mathematics communication of SI subject was fluent. In accordance with Margarani's [14] research that impulsive students are fluent in writing down all information to conclusions.

Then codes A.T.1 and C.T.1 indicate that the SI subject wrote all the known and asked information that relevant in the problem correctly in her own language. Following are the interviews with SI subject related to information that is known and asked in open-ended questions.

Researcher: What information do you get on this question?

\section{SI Subject}

The first test: There is a cloth measuring $250 \mathrm{~cm} \times 110 \mathrm{~cm}$. Bu Yuli bought 2 batik and 3 songkets at a price of 15 million 800 thousand. And Bu Lia bought 1 batik and 2 songkets at a price of 9 million 900 thousand. Then Bu Eka wanted to buy 10 cloths but with 30 million in cash. (A.L.1) (C.L.1)

The second test: Yuli bought 2 medical masks and 3 cloth masks for 18,500 and Lia bought 1 medical mask and 2 cloth masks for 10,000. (A.L.1) (C.L.1)

Researcher: What was asked on the question?

\section{SI Subject}

The first test: Can Mrs. Eka buy 10 cloths with this money. (A.L.1) (C.L.1)

The second test: Can Eka buy 10 masks for 30 thousand. (A.L.1) (C.L.1)

Figure 8 Interviews Transcript of SI about Known and Asked Information

Code A.L.1 C.L.1 on the interview transcript, the SI subject mentioned all known and asked information in open-ended questions fluently. It can be interpreted that written and oral mathematics communication of SI subjects were accurate, fluent and complete in mentioning related information that is known and asked in open-ended questions. In contrast to the results of Margarani's research [14] which stated that impulsive students are inaccurate and incomplete write things that are known and asked but can say accurately, fluently and correctly. This difference is because students are accustomed to writing down this information to make it easier to solve the questions, this goal is in accordance with Satriawan et al [18] who stated that students build impulsive connections about the entire problem by using information which has been known to answer the question. 
In relation to the strategies used in solving open-ended questions and their reasons, the researcher conducted interviews with SI subjects. The following are the interview regarding the strategy chosen by the SI subject and the reasons.

Researcher: How did you solve the problem?

SI Subject

The first test: Elimination and substitution. (A.L.2)

The second test: Same as yesterday combined elimination and substitution method. (A.L.2)

Researcher: Why did you choose this method?

SI Subject

The first test: Because when I learned these methods, including how to solve it that is quite easy. (A.L.2)

The second test: Because it is easier to use to solve the problem. (A.L.2)

Figure 9 Interview Transcript of SI about Solution Strategy

In the transcript of the interview, the SI subject mentioned the same strategy on both tests that she used to solve the questions and their reasons. This was true and relevant to the procedure she wrote down. Therefore, it can be said that the oral communication of the SI subject related to strategy was correct. This is in accordance with the research of Margarani [14] that impulsive student oral communication accurately explains the completion strategy.

In code A.T.3, the SI subject used an example in both tests to model the questions. However, this explanation was accurate in determining what aspects of the information the questions know about. This indicates that the written mathematics communication of the SI subject did not accurately used the term, mathematical notation in the problem. These results are in accordance with the research of L. Putri and Dwijanto [17] which stated that impulsive students cannot use mathematical notation appropriately.

Furthermore, about the completion steps written (in code A.T.4 and C.T.2) were correct and relevant to the SPLDV completion and elimination method. This indicates that written communication of the SI subject can be said to be inaccurate, complete and fluent regarding the steps for solving open-ended questions. The following are the interviews related to the explanation of the SI subject at the completion steps.

\section{Researcher: Try to explain the steps to solve the problems you have written" \\ SI Subject}

The first test: After recording what is known and asked, here batik uses the letter b code and songket uses the letter $s$. First by eliminating, $2 b+3 s=15,800,000$ and $1 b+2 s=9,900,000$ are eliminated by equating the b. $2 b+3 s=15,800,000$ minus $2 b+4 s=19,800,000$ gives $-s=-4,000,000$. In finding the negative s 4,000,000 divided by (-1), the price of sorbet fabrics is 4,000,000. (A.L.4) (L.L.2) (C.L.2)

Researcher: How come sorbet?

SI Subject: Oh i mean songket.

Researcher: Okay, continue.

SI Subject: Then use the substitution method, which is $1 b+2 s=9,900,000.1 \mathrm{~b}$ plus twice the price of one songket, which is $4,000,000=9,900,000.1 \mathrm{~b}+8,000,000=9,900,000$. The price of 1 batik is equal to $9,900,000-8,000,000$, get the result of the price of 1 batik 1,900,000. (A.L.4) (L.L.2) (C.L.2)

The second test: "I used a medical mask with the letter $\mathrm{m}$ code and a fabrics mask with the letter $\mathrm{k}$. $2 \mathrm{~m}+3 \mathrm{k}=18,500,1 \mathrm{~m}+2 \mathrm{k}=10,000$. Using the elimination method, the $\mathrm{k}$ is equalized, this is the top multiplied by 2 , the bottom multiplied by $3.4 \mathrm{~m}+6 \mathrm{k}=37,000,3 \mathrm{~m}+6 \mathrm{k}=30,000$ minus the price of 1 medical mask 7,000. The second I use substitution, I take the easy formula, bu lia, $1 \mathrm{~m}+2 \mathrm{k}=$ 10,000 . It is known that the price of 1 medical mask is $7,000,7,000+2 \mathrm{k}=10,000$. To find $2 \mathrm{k}=$ 10,000-7000. Then found the price of 1 fabrics mask 1,500. (A.L.4) (L.L.2) (C.L.2)

\section{Figure 10 Interview Transcript of SI about Solution Steps}

Based on the results of the interview, in both tests, the SI subject was correct in explaining the steps for completion, both the elimination and substitution methods, using their own language, and in explaining them. However, the SI subject has not used sentences, 
appropriate mathematical terms when describing the steps of solving such as taking an example, misinterpreting variables, and calling equations into formulas. This precludes verbal communication in mentioning notation; the term mathematical symbol was not accurate. These errors were in accordance with the characteristics of an impulsive cognitive style, inadequate accuracy and accuracy [17]. Based on the above analysis, communication both oral and written of SI subject can be said inaccurate, complete and fluent in terms of mentioning the steps for solving open-ended questions. This is in accordance with the results of Shodiqin's [16] research that impulsive students can complete the completion steps and were able to communicate them completely and clearly even though there are still some mistakes.

As a result of the SI subject's mistakes in the first test, one of the alternative answers she wrote (codes A.T.5 and C.T.3) also incorrectly mentioned the type of fabrics. However, the other alternative solutions and the conclusions written by SI subject on both tests were in accordance with what was asked in the questions. In addition, the SI subject was able to write more than one alternative correct answer according to their opinion and in their own language. Therefore the written communication ability of SI subject in mentioning alternative solutions and conclusions is inaccurate and incomplete. The following are the regarding the conclusion of the completion of open-ended questions on the SI subject.

\section{Researcher: Ok, now try to explain the solution and conclusion to the problem. \\ SI Subject}

The first test: The question was, can Bu Eka buy 10 pieces of cloth with 30 million in cash. So, it could be if Mrs. Eka buys half batik cloth and half songket cloth, it means buying 2 types of cloth mixed like that. For example, buying 5 batik cloths at a price of 9,500,000 and 5 songket cloths at a price of 20,000,000 add up the price to 29,500,000 minus the money that Bu Eka brought, still leaving 500,000. It could also be if Mrs. Eka bought 10 batik cloths, the price of 10 batik cloth was 19,000,000, if it was deducted from the money that Bu Eka brought, she still left 11,000,000. But Bu Eka could not buy it if Bu Eka bought 10 songket cloths, 10 songket cloths cost 40,000,000 while the money that Mrs. Eka brought was only 30,000,000. In conclusion, the problem can be solved in various ways. (A.L.5) (L.L.4) (C.L.3)

The second test: The answer is that Eka can buy 10 masks with 30,000 money if Eka buys 10 cloth masks or can buy several cloth masks and masks with a total of 10 pieces. However, Mrs. Eka could not buy 10 medical masks with a budget of 30,000 because from the price of 1 medical mask 7,000, 10 medical masks were 70,000 while Mrs. Eka's money was 30,000. If Mrs. Eka buys 10 cloth masks, she still can because the price of 1 cloth mask is 1,500 if she buys 10 cloth masks 15,000 . (A.L.5) (L.L.4) (C.L.3)

Researcher: Why did you write down 3 solutions in the first test while the second test wrote 2 solutions?

SI Subject: Because the first problem is similar to the second, I want to summarize it in the second solution.

Figure 11 Interview Transcript of SI about Solution and Conclusion

The SI subject was able to explain the alternative of correct and relevant problem solving without stuttering. In addition, she had realized the error writing of songket before, so that the explanation of the arguments she presented was also has same errors. She wrote more than one correct completion on tests, 3 completions on the first test and 2 completions on the second test. The difference in the number of solutions she wrote was because she realized that the two problems were similar so she wanted to communicate her ideas more concisely. Based on this analysis, the oral communication of SI subject in mentioning problem solving and conclusions was accurate, complete and fluent. In contrast to the results of Margarani's [14] research, impulsive students are inaccurate, incomplete and fluent in expressing conclusions both in writing and orally. This difference could be due to the previous skill of impulsive students that being able to communicate both in writing and orally related information that was known, asked about, completion strategies and even completion steps completely, fluently even though there are small errors. With this ability, it allowed her to be able to mention alternative solutions and draw conclusions completely, fluently, and inaccurately. 


\section{Conclusion}

Reflective student's written mathematics communication: she fluently writes all information to conclusions, accurately and completely mentions the known and asked information also in mentioning the steps solution, mentions alternative solutions and conclusions, but inaccurately uses mathematical terms/ notations. Her oral communication: she fluently, accurately but incompletely mentions the known and asked information, she accurately mentions the strategies but inaccurately mentions mathematical terms/notations, she is not fluently, inaccurately but completely mentions the solution steps, accurately, completely and fluently mentions the alternatives solutions and conclusions. Meanwhile written mathematics communication of impulsive student: she fluently writes all information to conclusions, accurately and completely mentions the information that was known and asked but inaccurately uses mathematical terms/notations, she completely but inaccurately mentions the steps solution, the alternative solutions also the conclusions. Her oral communication: she accurately mentions the strategies but inaccurately mentions mathematical terms/notations, she fluently, accurately and completely mentions the known and asked information also mentions steps for solutions, alternative solutions and conclusions.

\subsection{Suggestion}

Teachers should more often give students open-ended questions to solve in a lesson with the aim of developing student mathematics communication, providing a lot of experience for students solving various types of questions by paying attention to differences in cognitive styles of reflective and impulsive students. For other researchers, they should provide more indepth questions when interviewing research subjects so that the data obtained is more detailed and in-depth.

\section{Reference}

[1] N. S. R. Rohid and D. Retno. Students' Mathematical Communication Skills (MCS) in Solving Mathematics Problems: A Case in Indonesian Context. Anatol. J. Educ., vol. 4, no. 2, pp. 19-30, Oct. 2019.

[2] A. D. Wijayanto, S. N. Fajriah, and I. W. Anita, "ANALISIS KEMAMPUAN KOMUNIKASI MATEMATIS SISWA SMP PADA MATERI SEGITIGA DAN SEGIEMPAT," J. Cendekia J. Pendidik. Mat., vol. 2, no. 1, pp. 97-104, May 2018, doi: 10.31004/cendekia.v2i1.36.

[3] H. Rizqi Yunitiara and S. B. W. Wiyanto. Mathematics Communication Skill Viewed from Self-Confidence in Auditory Intellectually Repetition (AIR) Learning Model with RME Approach. Unnes J. Math. Educ. Res. 2021; 10(2): 162-167.

[4] D. Wahyuningrum, Endang and Suryadi. Association of Mathematical Communication and Problem Solving Abilities: Implementation of MEAs Strategy in Junior High School. SAINSAB. 2014; 17(2)

[5] W. Wulandari. Eksperimentasi Problem Based Instruction (PBI) Dengan Open Ended Dan Closed Ended Ditinjau Dari Kemampuan Awal Terhadap Prestasi Belajar Pada Materi Lingkaran Siswa Kelas VIII Semester Genap SMP Negeri 1 Sukodono Tahun Ajaran 2014/2015. Diss. Universitas Muhammadiyah Surakarta, 2015.

[6] Y. Sapitri, C. Utami, and M. Mariyam, "Analisis Kemampuan Pemecahan Masalah Matematis Siswa dalam Menyelesaikan Soal Open-Ended pada Materi Lingkaran Ditinjau dari Minat Belajar," Variabel, vol. 2, no. 1, p. 16, May 2019, doi: 10.26737/var.v2i1.1028.

[7] C. Züll, "Open-Ended Questions," GESIS - Leibniz Inst. Soc. Sci., 2016, doi: 10.15465/gesis-sg_en_002.

[8] A. Copeland, "The Pros and Cons of Open and Closed Questions Closed Questions Usually Start With," Mar. 2017. Accessed: Aug. 19, 2020. [Online]. Available: http://environment.uwaterloo.ca/research/watgreen/projects/library/1020/ocq.html.

[9] I. M. Azhil and A. Ernawati, "PROFIL PEMECAHAN MASALAH SISWA SMP PADA MATERI PERBANDINGAN DITINJAU DARI GAYA KOGNITIF 
REFLEKTIF DAN IMPULSIF," Semin. Nas. Pendidik. Mat. Ahmad Dahlan, vol. 1, no. 0, pp. 125-129, Jan. 2018, Accessed: Jul. 19, 2020. [Online]. Available: http://seminar.uad.ac.id/index.php/sendikmad/article/view/23.

[10] D. Nur Arofah and Masriyah, "PROFIL PENGAJUAN MASALAH MATEMATIKA SISWA SMP DITINJAU DARI GAYA KOGNITIF REFLEKTIF DAN IMPULSIF," $J$. Ilm. Pendidik. Mat., vol. 8, no. 2, Jun. 2019, Accessed: Dec. 16, 2020. [Online]. Available: https://jurnalmahasiswa.unesa.ac.id/index.php/mathedunesa/article/view/27975.

[11] M. Gani, S. Tahmir, and Asdar. Deskripsi Kemampuan Memecahkan Masalah Matematika Open Ended Ditinjau dari Gaya Kognitif Siswa Kelas IX SMP Negeri 1 Suli. Pedagogy. 2016; 3(2): pp. 79-150.

[12] N. L. Noor. PENINGKATAN KEMAMPUAN KOMUNIKASI MATEMATIS PESERTA DIDIK MELALUI OPEN ENDED PROBLEM. Elem. Islam. Teach. J.. 2020 $8(2)$.

[13] Sugiyono. Metode Penelitian Kuantitatif, Kualitatif, dan $R \& D$. Cetakan-1. Bandung: Alfabeta, 2019.

[14] R. Margarani and Ismail. PROFIL KEMAMPUAN KOMUNIKASI MATEMATIKA SISWA DALAM MEMECAHKAN MASALAH MATEMATIKA DITINJAU DARI GAYA KOGNITIF REFLEKTIF-IMPULSIF. MATHEdunesa J. Ilm. Pendidik. Mat. 2017;3(5)

[15] A. Shodiqin, S. B. Waluya, Rochmad, and Wardono. Mathematics communication ability in statistica materials based on reflective cognitive style. Journal of Physics: Conference Series. 202; 1511(1).

[16] A. Shodiqin and M. S. Zuhri. BERPIKIR IMPULSIF DALAM KOMUNIKASI MATEMATIS SISWA SEKOLAH MENENGAH PERTAMA. PYTHAGORAS J. Progr. Stud. Pendidik. Mat. 2018; 7(2); pp. 68-73,

[17] S. L. Putri, Dwijanto. Analysis of Mathematical Communication Skills and Confidence of 10th Grader of SMK in Geometry Material Viewed from Cognitive Style. Unnes J. Math. Educ. 2017; 6(1): pp. 97-107.

[18] M. A. Satriawan, M. T. Budiarto, and T. Y. E. Siswono. Students' Relational Thinking of Impulsive and Reflective in Solving Mathematical Problem. Journal of Physics: Conference Series. 2018; 947(1): 12030. 